\title{
3 แ
}

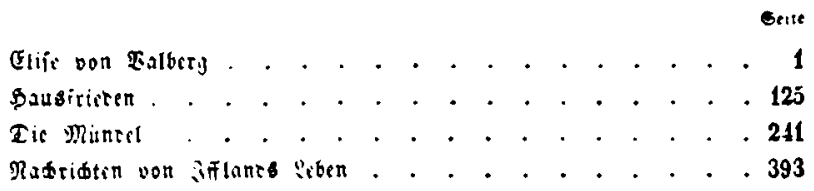


